Journal Club

Editor's Note: These short reviews of recent JNeurosci articles, written exclusively by students or postdoctoral fellows, summarize the important findings of the paper and provide additional insight and commentary. If the authors of the highlighted article have written a response to the Journal Club, the response can be found by viewing the Journal Club at www.jneurosci.org. For more information on the format, review process, and purpose of Journal Club articles, please see http://jneurosci.org/content/ preparing-manuscript\#journalclub.

\title{
The Integrated Stress Response Is Not a Target for Diffuse White Matter Injury in Premature Infants
}

\author{
Nafisa M. Jadavji \\ Department of Neuroscience, Carleton University, Ottawa, Ontario K1S 5B6, Canada \\ Review of Clayton et al.
}

Loss of premyelinating oligodendrocytes during early neurodevelopment is a problem of great importance because the effects are long lasting. Approximately 60,000 infants are affected yearly in the United States with some type of white matter injury (Osterman et al., 2015). By school age, some of these infants develop cognitive impairments and learning disabilities (Counsell et al., 2003). These impairments have been reported to continue into adulthood (Allin et al., 2011). Exposure to hypoxia before myelination leads to the loss of premyelinating oligodendrocytes, which results in diffuse white matter injury (DWMI) in infants born between 23 and 32 weeks of gestation (Clayton et al., 2017). Hypoxic conditions in the developing brain can be caused by reduced oxygen from underdeveloped lungs or neural vasculature (Volpe, 2009). As the care of premature infants is improving and imaging techniques are advancing, the prevalence and ability to detect DWMI are increasing (Cooke, 1999; Heuchan et al., 2002). Currently, there are no therapies to treat DWMI. For therapeutic progress to be

Received Sept. 20, 2017; revised 0ct. 31, 2017; accepted Nov. 2, 2017.

N.M.J. was supported by the Natural Science and Engineering Research Council postdoctoral fellowship.

The authors declare no competing financial interests.

Correspondence should be addressed to Dr. Nafisa M. Jadavji, Depart-

ment of Neuroscience, Carleton University, 1125 Colonel By Drive, Ottawa, Ontario K1S 5B6, Canada. E-mail: nafisa.jadavji@mail.mcgill.ca.

DOI:10.1523/JNEUROSCI.2763-17.2017

Copyright $\odot 2017$ the authors $\quad 0270-6474 / 17 / 3711772-02 \$ 15.00 / 0$ made, it is imperative to elucidate the mechanisms that make the developing brain more vulnerable to DWMI.

Previous work has suggested that the integrated stress response (ISR) is involved in protecting oligodendrocytes from damage (Lin et al., 2007). The ISR is an elaborate signaling pathway that is activated when cells are exposed to physiological changes or to pathological conditions, such as hypoxia. The ISR is an important cellular response that controls translation and mounts protective reactions. Central to the ISR is the activation of the $\alpha$ subunit of eukaryotic translation initiation factor 2 (eIF2 $\alpha$ ) by phosphorylation of serine 51 . This kinase is an early responder to disturbances in cellular homeostasis, and once activated, it triggers a decrease of most protein synthesis, which allows translation of specific genes. There are four members of the eIF2 $\alpha$ kinase family, including protein kinase RNA-activated-like endoplasmic reticulum (ER) kinase (PERK), which is in the ER where it is thought to be activated by stress, such as hypoxia.

A recent study published in The Journal of Neuroscience by Clayton et al. (2017) investigated whether the ISR has a protective role in DWMI. They hypothesized that the PERK arm of the ISR may protect premyelinating oligodendrocytes from hypoxia. In support of this hypothesis, the authors found that, by inhibiting ISR in primary mouse oligodendrocyte precursor cells, they were more susceptible to damage from hypoxia than controls. Furthermore, deletion of PERK increased hypoxia-induced damage in cultured oligodendrocyte precursor cells. In contrast, results from two in vivo mouse models of DWMI, mild chronic hypoxia $(\mathrm{MCH})$ and severe acute hypoxia (SAH), were inconsistent with a role for the ISR in protecting oligodendrocyte precursor cells from hypoxia. Although hypoxia increased phosphorylation of eIF $2 \alpha$ in these models, no downstream components of the ISR were affected. Indeed, the levels of one of the genes activated by $\operatorname{eIF} 2 \alpha$, transcription factor 4 , which aids in cell survival and recovery (Pakos-Zebrucka et al., 2016), were decreased in the CNS after MCH and SAH. Moreover, loss of PERK did not affect damage induced by $\mathrm{MCH}$ or SAH. Furthermore, when the authors enhanced components of the ISR by increasing levels of activating growth and arrest DNA damage 34 (GADD34) and transcription factor, CAAT enhancer binding protein homologous protein (CHOP), there was no protection provided to animals with $\mathrm{MCH}$ and SAH. Based on these results, the authors concluded that the PERK arm of ISR is not a promising target for treating DWMI (Clayton et al., 2017).

Even though PERK does not appear to be beneficial in DWMI, other components of the ISR may be involved in protecting premyelinating oligodendrocytes from hypoxia. Clayton et al. (2017) reported that reduced levels of PERK in 
mouse models of DWMI resulted in higher levels of phosphorylated double-stranded RNA-dependent protein kinase (PRK), another member of the eIF $2 \alpha$ kinase family. PRK is activated by double-stranded RNA during viral infections in mammals (Pakos-Zebrucka et al., 2016); it can also be activated by oxidative and ER stress (Shimazawa and Hara, 2006; Lee et al., 2007). Furthermore, PRK can be stimulated by caspase activity during early cell death processes potentially playing a role in protein synthesis during this process (Saelens et al., 2001). This may be of importance when it comes to premyelinating oligodendrocytes, as it is a part of the ISR, which has been implicated in DWMI. More investigation into the role of PRK arm of the ISR in hypoxic cell death of premyelinating oligodendrocytes is therefore warranted.

To promote the survival of premyelinating oligodendrocytes, creating an environment that promotes cell survival within the premature brain may be key for future therapeutic development. One avenue that might be pursued is reducing the free-radical attack on premyelinating oligodendrocytes, including microglial, by decreasing oxidative stress and replenishing antioxidant defenses. There is a high amount of microglial activation after hypoxia in the premature brain, and these immune cells generate a significant amount of reactive oxygen species (Haynes et al., 2003). Microglial activation in combination with the reduced antioxidant defense system that is present in the premature brain may create an environment detrimental to survival of premyelinating oligodendrocytes (Khwaja and Volpe, 2008). Reducing microglial activation in the premature brain may be a potential target for reducing death of premyelinating oligodendrocytes; however, further investigation is required.

Excitotoxicity may be another pathway through which premyelinating oligodendrocyte cell death occurs in the premature brain. There are a few avenues through which exocytotic cell death may occur, first, through high levels of the main excitatory neurotransmitter, glutamate. It has been reported that high levels of glutamate are present because of reduced glutamate uptake in the premature brain after hypoxia (Matute et al., 2001). Additionally, AMPA receptors are overexpressed in the devel- oping brain specifically in premyelinating oligodendrocytes (Talos et al., 2006), and their activation could lead to excitotoxic cell death. Last, the NMDA receptors are highly expressed on oligodendrocytes, and these receptors are permeable to calcium (Salter and Fern, 2005). High levels of calcium in the cell are known to result in exocytotic cell death. As the prevalence of DWMI is increasing, research in the field needs to focus on therapeutic targets. The study by Clayton et al. (2017) reports important negative results that contribute to the development and investigation of potential therapies for DWMI.

Within the biomedical field, there has been a low rate of reproducibility of research possibly because of the push to publish significant results (Joober et al., 2012), which has triggered many clinical trials to fail (Song et al., 2012). The study by Clayton et al. (2017) does indeed move the field of DWMI therapeutic forward, but by presenting negative results that eliminate the PERK component of the ISR as a potential therapeutic target. These data have advanced the field in that other signaling pathways can be targeted to for future therapeutic development.

\section{References}

Allin MP, Kontis D, Walshe M, Wyatt J, Barker GJ, Kanaan RA, McGuire P, Rifkin L, Murray RM, Nosarti C (2011) White matter and cognition in adults who were born preterm. PLoS One 6:1-9. CrossRef Medline

Clayton BL, Huang A, Kunjamma RB, Solanki A, Popko B (2017) The integrated stress response in hypoxia-induced diffuse white matter injury. J Neurosci 37:7465-7480. CrossRef Medline

Cooke RW (1999) Trends in incidence of cranial ultrasound lesions and cerebral palsy in very low birthweight infants 1982-93. Arch Dis Child Fetal Neonatal Ed 80:F115-F117. CrossRef Medline

Counsell SJ, Allsop JM, Harrison MC, Larkman DJ, Kennea NL, Kapellou O, Cowan FM, Hajnal JV, Edwards AD, Rutherford MA (2003) Diffusionweighted imaging of the brain in preterm infants with focal and diffuse white matter abnormality. Pediatrics 112:1-7. CrossRef Medline

Haynes RL, Folkerth RD, Keefe RJ, Sung I, Swzeda LI, Rosenberg PA, Volpe JJ, Kinney HC (2003) Nitrosative and oxidative injury to premyelinating oligodendrocytes in periventricular leukomalacia. J Neuropathol Exp Neurol 62:441-450. CrossRef Medline

Heuchan AM, Evans N, Henderson Smart DJ, Simpson JM (2002) Perinatal risk factors for major intraventricular haemorrhage in the Australian and New Zealand Neonatal Net- work, 1995-97. Arch Dis Child Fetal Neonatal Ed 86:F86-F90. CrossRef Medline

Joober R, Schmitz N, Annable L, Boksa P (2012) Publication bias: what are the challenges and can they be overcome? J Psychiatry Neurosci 37:149-152. CrossRef Medline

Khwaja O, Volpe JJ (2008) Pathogenesis of cerebral white matter injury of prematurity. Arch Dis Child Fetal Neonatal Ed 93:F153-F161. CrossRef Medline

Lee ES, Yoon CH, Kim YS, Bae YS (2007) The double-strand RNA-dependent protein kinase PKR plays a significant role in a sustained ER stress-induced apoptosis. FEBS Lett 581: 4325-4332. CrossRef Medline

Lin W, Bailey SL, Ho H, Harding HP, Ron D, Miller SD, Popko B (2007) The integrated stress response prevents demyelination by protecting oligodendrocytes against immunemediated damage. J Clin Invest 117:448-456. CrossRef Medline

Matute C, Alberdi E, Domercq M, Pérez-Cerdá F, Pérez-Samartín A, Sánchez-Gómez MV (2001) The link between excitotoxic oligodendroglial death and demyelinating diseases. Trends Neurosci 24:224-230. CrossRef Medline

Osterman MJ, Kochanek KD, MacDorman MF, Strobino DM, Guyer B (2015) Annual summary of vital statistics: 2012-2013. Pediatrics 135:1115-1125. CrossRef Medline

Pakos-Zebrucka K, Koryga I, Mnich K, Ljujic M, Samali A, Gorman AM (2016) The integrated stress response. EMBO Rep 17:1374-1395. CrossRef Medline

Saelens X, Kalai M, Vandenabeele P (2001) Translation inhibition in apoptosis: caspasedependent PKR activation and eIF2-alpha phosphorylation. J Biol Chem 276:41620-41628. CrossRef Medline

Salter MG, Fern R (2005) NMDA receptors are expressed in developing oligodendrocyte processes and mediate injury. Nature 438:11671171. CrossRef Medline

Shimazawa M, Hara H (2006) Inhibitor of double stranded RNA-dependent protein kinase protects against cell damage induced by ER stress. Neurosci Lett 409:192-195. CrossRef Medline

Song F, Hooper L, Loke YK, Joober R, Schmitz N, Annable L, Boksa P (2012) Publication bias: what is it? How do we measure it? How do we avoid it? J Psychiatry Neurosci 5:149-152.

Talos DM, Fishman RE, Park H, Folkerth RD, Follett PL, Volpe JJ, Jensen FE (2006) Developmental regulation of $\alpha$-amino-3-hydroxy5-methyl-4-isoxazole-propionic acid receptor subunit expression in forebrain and relationship to regional susceptibility to hypoxic/ischemic injury: I. Rodent cerebral white matter and cortex. J Comp Neurol 497:42-60. CrossRef Medline

Volpe JJ (2009) Brain injury in premature infants: a complex amalgam of destructive and developmental disturbances. Lancet Neurol 8:110-124. CrossRef Medline 